\title{
CONTRIBUIÇÃO DE MELHORIA: \\ LIMITES UTILIZADOS NO SISTEMA TRIBUTÁRIO BRASILEIRO
}

\section{Mateus de Andrade Carvalho ${ }^{1}$ Leonardo Gonçalves Muraro²}

Resumo: O presente artigo tem como objetivo analisar a contribuição de melhoria, tributo que consiste no ressarcimento ao poder público dos gastos oriundos da realização de obras públicas, das quais ocorreu valorização dos imóveis beneficiados. Baseia-se no princípio da demonstração da valorização imobiliária pelo ente público que realiza a obra, respeitando os limites aplicados à sua cobrança, individual (valorização imobiliária) e global (custo total). O debate apresenta-se no sentido da omissão do texto constitucional, ao não mencionar a necessidade da demonstração da valorização imobiliária e tampouco os limites, individual e global, como elementos da contribuição de melhoria. Deixa-se, desta forma, margem a discussões e entendimentos contrários, que serão debatidos e confrontados neste artigo, a fim de identificar as dificuldades na correta aplicação do tributo frente aos preceitos legais, doutrinários, sociais e políticos que o cercam. Deste modo, verificando entendimento dos tribunais superiores e da maioria doutrinária, no sentido da necessidade de demonstração da valorização dos imóveis como fato gerador do tributo, assim como a recepção dos limites pela Constituição Federal, nos termos do Código Tributário Nacional e do Decreto-Lei 195/67.

Palavras-chave: contribuição de melhoria. valorização imobiliária. limites.

Abstract: This article aims to analyze the improvement contribution, tribute consisting of compensation to the government of the expenses arising from the implementation of public works, which occurred valuation of real benefit. It is based on the principle of demonstration of real estate valuation by the public entity that performs the work, within the limits applied to your collection, individual (real estate valuation) and overall (total cost). The debate is presented towards the constitutional text omission to not mention the need for demonstration of real estate valuation, nor the limits, individual and global, as elements of improved contribution. Let it thus rise to contrary discussions and understandings that will be discussed and compared in this article in order to identify the difficulties in the correct application of the tax compared to the legal provisions, doctrinal, social and political that surround it. Thus, checking understanding of the higher courts and most doctrinaire, on the need to demonstrate the value of the property as generating tribute, as well as the reception of bounds by the Constitution, in accordance with the National Tax Code and Decree-Law 195/67.

Keywords: improvement contribution. real estate valuation. limits.

\footnotetext{
${ }^{1}$ Acadêmico do Curso de Direito da UNICNEC, de Osório.

${ }^{2}$ Prof. Me. em Direito, na UNICNEC, de Osório.
} 


\section{INTRODUÇÃO}

A contribuição de melhoria está prevista no Brasil no Código Tributário Nacional, em seus artigos 81 e 82, regulamentada de forma específica no DecretoLei $\mathrm{n}^{\circ}$ 195, de 24 de fevereiro de 1967 e recepcionada no texto constitucional no art. 145, III, da Constituição Federal de 1988. Esse tributo visa o ressarcimento ao poder público dos gastos decorrentes de obras públicas que, de forma direta ou indireta, beneficiaram determinados imóveis, ocasionando a valorização imobiliária dos mesmos.

Faz-se relevante o debate acerca da contribuição de melhoria, tendo em vista a contemporaneidade desta matéria e as inúmeras controvérsias que envolvem o tema. A contribuição de melhoria surge como uma alternativa para que o poder público, em épocas de crise e instabilidade econômica, ou, mesmo para manter o equilíbrio do sistema tributário nacional, encontre formas de manter o investimento em obras de infraestrutura e mobilidade urbana e da mesma forma não onerem de forma excessiva as finanças públicas.

Nesse contexto busca-se analisar as características da contribuição de melhoria mais específicamente no que tange aos limites (valorização individual e custo total) a sua cobrança. Assim como a necessidade da demonstração da valorização imobiliária como fato gerador da cobrança do tributo, contrapondo a influência do sistema adotado no Brasil, com sua pouca utilização no ordenamento tributário pátrio.

Identificando, deste modo, a influência dos limites à cobrança da contribuição de melhoria na aplicabilidade do tributo; definindo entendimentos doutrinários majoritários e minoritários acerca da necessidade da valorização imobiliária como fato gerador da cobrança da contribuição de melhoria. Confrontando a forma como é aplicada a contribuição de melhoria no Brasil e como outros ordenamentos jurídicos pelo mundo analisam e aplicam este tributo.

Da mesma forma se faz necessária a compreensão dos fatores que dificultam a cobrança da contribuição de melhoria no Brasil, tanto jurídicos, quanto políticos, não obstando como objeto desse artigo esgotar as discussões e elucidar todos os 
problemas frente à extensão e complexidade da matéria. Vislumbra este trabalho, buscar de certa forma, formular um entendimento teórico acerca da matéria, e o porquê de ser considerado um tributo esquecido pela maioria da doutrina.

\section{HISTÓRICO}

A ideia basilar de ressarcimento ao erário público dos gastos oriundos de obras públicas que gerarem valorização imobiliária aos proprietários dos imóveis beneficiados remonta de muito tempo. Aperfeiçoou-se, ao longo dos anos, essa prática até chegar-se hoje à contribuição de melhoria como se conhece. Há registros datados do século XI quando, em Florença, na Itália, em 1296, foi cobrado por obras de ampliação de uma praça e, em Londres, em 1250, pelas obras de construção de diques para o rio Tâmisa. No Brasil, são encontrados indícios de cobrança semelhante desde os tempos do império e, mais recentemente, no início do século XX em 1905, para indenizar o custo da pavimentação de ruas no Distrito Federal; galgando, veio até ser recepcionada, de fato, pela primeira vez, na Constituição de 1934, já denominada por sua nomenclatura atual ${ }^{3}$.

Entretanto na Constituição de 1937, a contribuição de melhoria é ignorada pelo texto legislativo, dando a falsa impressão de ter-se transformado em taxa. Ideia essa, refuta em manifestação de STF em 1943, ainda na vigência da referida Carta, no RE $n$ 5.500/RS, onde o ministro Philadelpho Azevedo, reconheceu a constitucionalidade do tributo como contribuição de melhoria ${ }^{4}$.

A Carta Magna de 1946 apresenta novamente a contribuição de melhoria com previsão na legislação maior, reforçando no texto constitucional a necessidade da valorização como fato gerador do tributo.

\footnotetext{
${ }^{3}$ SILVA, Edgar Neves da. Contribuição de Melhoria. In: MARTINS, Ives Gandra da Silva (Coord.). Curso de Direito Tributário. 13. ed. São Paulo: Saraiva, 2011. P. 1069.

${ }^{4}$ SABBAG, Eduardo. Manual de Direito Tributário. 3. ed. São Paulo: Saraiva, 2011. P. 447.
} 
Em primeiro de dezembro de 1965, foi promulgada pela Câmara dos Deputados a emenda constitucional $n^{-} 18 / 65^{5}$ que assim foi conceituada por Eduardo Sabbag:

A Emenda n. 18/65 manteve a menção aos limites total e individual, mas disciplinou que o tributo estaria destinado a ressarcir os cofres públicos dos custos da obra publica realizada. Nessa medida, a Emenda inaugurou um caráter hibrido a contribuição de melhoria, na medida em que esta passou a se lastrear, simultaneamente, no custo da obra e na mais-valia imobiliária ${ }^{6}$.

Dessa forma disciplina o ínclito doutrinador no sentido da Emenda n. 18/65 trazer aos fundamentos do instituto da contribuição de melhoria, os limites a cobrança, global e individual do tributo, assim como a sua destinação como ressarcimento ao erário público dos gastos oriundos de obras públicas, das quais decorre valorização dos imóveis beneficiados.

No seguimento legislativo histórico, a contribuição de melhoria obteve regramento objetivo em dois momentos, em 1966 com a publicação do Código Tributário Nacional ${ }^{7}$ (CTN), que além do Tributo em questão trata de toda a ordem tributária pátria. Um pouco mais adiante em 1967 com a publicação do Decreto-Lei n. $195^{8}$ que veio para regulamentar de forma específica a instituição pelo Estado da contribuição de melhoria.

As constituições seguintes de 1967 e em 1969 com a emenda constitucional n.1 mantiveram o gravame da contribuição de melhoria em seus artigos, nesta no artigo $18, I I^{9}$, naquela no artigo $19, \mathrm{III}, \S^{3^{\circ 10}}$.

\footnotetext{
${ }^{5}$ Art. 19. Compete à União, aos Estados, ao Distrito Federal e aos Municípios, no âmbito de suas respectivas atribuições, cobrar contribuição de melhoria para fazer face ao custo de obras públicas de que decorra valorização imobiliária, tendo como limite total a despesa realizada e como limite individual o acréscimo de valor que da obra resultar para cada imóvel beneficiado. BRASIL. Emenda Constitucional № 18, de 1ํ de Dezembro de 1965. Reforma do Sistema Tributário. Disponível em: http://www.planalto.gov.br/ccivil_03/Constituicao/Emendas/Emc_anterior1988/emc18-65.htm. Acesso em: 06/06/2016.

${ }^{6}$ SABBAG, Eduardo. Manual de Direito Tributário. 3. ed. São Paulo: Saraiva, 2011. P. 447.

${ }^{7}$ BRASIL. Lei no 5.172, de 25 de outubro de 1966. Dispõe sobre o Sistema Tributário Nacional e institui normas gerais de direito tributário aplicáveis à União, Estados e Municípios. Disponível em: http://www.planalto.gov.br/ccivil_03/leis/L5172Compilado.htm. Acesso em: 05 jun. 2016.

${ }^{8}$ BRASIL. Decreto-Lei № 195, De 24 De Fevereiro De 1967. Dispõe sobre a cobrança da Contribuição de Melhoria. Disponível em < http://www.planalto.gov.br/ccivil_03/decretolei/del0195.htm>. Acesso em: 26 jun. 2016.

${ }^{9}$ BRASIL. Constituição da República Federativa do Brasil de 1967. Disponível em:

<http://www.planalto.gov.br/ccivil_03/Constituicao/Constituicao67.htm>. Acesso em: 23 mai. 2016.

${ }^{10}$ BRASIL. Emenda Constitucional № 1, de 17 de Outubro de 1969. Disponível em:
} 
Por fim a Constituição Federal de 1988 recepcionou do mesmo modo a contribuição de melhoria como espécie tributária, porém com um texto conciso e vago, deixou muitas perguntas acerca da correta instituição do tributo. Por trazer em seu artigo 145, III, apenas texto singelo restando silente aos limites da cobrança, individual e global e a necessidade da valorização do imóvel como fato gerador da cobrança do tributo $^{11}$.

Assim, a instituição da contribuição de melhoria, no ordenamento jurídico nacional como tributo, trouxe ao Brasil, a possibilidade de utilizar-se dessa espécie tributária tão antiga e por deveras útil ao sistema tributário salutar que visa à correta divisão de encargos e vantagens entre os seus contribuintes.

\section{A CONTRIBUIÇÃO DE MELHORIA PELO MUNDO}

A contribuição de melhoria, como instituto tributário, apresenta, ao debate dogmático e doutrinário, questões acerca de seu modelo, diferente em diversos países, e que, por esse motivo, obteve, de forma diversa, a aceitação e utilização pelos referidos sistemas jurídicos tributários. Edgar Neves da Silva, em texto seu escrito no Curso de Direito Tributário, organizado por Ives Gandra da Silva Martins, remonta um breve comparativo entre a contribuição de melhoria em alguns países. $\mathrm{Na}$ Inglaterra, na França e na Itália, os insucessos da tentativa de aplicação do tributo tornaram-no obsoleto e sem utilidade, tendo, principalmente na Itália, sistema que influencia nosso código tributário, situação muito semelhante à apreciada no Brasil. Na Alemanha, nos Estados Unidos e em alguns países da América do Sul, como Peru e Colômbia; entretanto, o tributo é cobrado com sucesso, tendo, em alguns casos, muitas diferenças do modelo aplicado no Brasil e, em outros, semelhanças com poucas alterações. ${ }^{12}$

http://www.planalto.gov.br/ccivil_03/Constituicao/Constituicao67EMC69.htm. Acesso em: 13 mai. 2016.

${ }^{11}$ BRASIL. Constituição Federal, Código Tributário, Código Comercial. 9. ed. Porto Alegre: Verbo Jurídico, 2010.

${ }^{12}$ SILVA, Edgar Neves da. Contribuição de Melhoria. In: MARTINS, Ives Gandra da Silva (Coord.). Curso de Direito Tributário. 13. ed. São Paulo: Saraiva, 2011. P. 1070. 
Denominada pelo mundo como betterment tax, na Inglaterra, special assement, nos Estados Unidos, contribuition sur lês plus values, na França, contributi di migliori, na Itália, erschliessungsbeitrag, na Alemanha, e contribución de Mejoras, na Espanha e nos países latinos ${ }^{13}$.

Restringiremos a análise neste momento, a dois modelos ambíguos de contribuição de melhoria, o modelo americano, baseado na valorização dos imóveis e no modelo alemão, cujo custo total da obra enseja a cobrança do tributo.

Nos modelos, americano e alemão, ambos com sucesso e aplicabilidade, é objetivado uma forma diferente de base de cálculo para a instituição da contribuição de melhoria. No modelo alemão baseia-se o cálculo do tributo no rateio do custo total da obra pelos contribuintes beneficiados, ou seja, se for realizada uma obra no valor de $\mathrm{R} \$ 100.000,00$ reais e tivermos 100 contribuintes beneficiados, o valor total será dividido igualmente por todos, restando um valor de $R \$ 1.000,00$ reais para cada contribuinte. A maior crítica à aplicabilidade do modelo alemão está no alto custo ao contribuinte, tendo em vista que os setores, principalmente no Brasil, que mais necessitam de investimento em infraestrutura, são os mais carentes e por isso os que detêm menor capacidade contributiva tributária. ${ }^{14}$

Neste sentido manifesta-se o professor Eduardo Sabbag em seus ensinamentos acerca do tema, "Disso decorre que o modelo alemão, longe de realizar a justiça fiscal, em nossas terras, tende a recrudescer a regressividade no sistema tributário brasileiro, promovendo desigualização, no lugar de isonomia"15. Dessa forma, verifica-se que, mesmo mais simples, e entendido por parte minoritária da doutrina como saída para a utilização da contribuição de melhoria, o modelo alemão embora efetivo no país saxão, mostra-se de difícil aplicabilidade à realidade desigual brasileira.

De outro modo apresenta-se o modelo americano, que se revela ao revés do alemão. No supracitado modelo americano, a base de cálculo da contribuição de melhoria se tem a partir da comprovação da valorização dos imóveis beneficiados,

\footnotetext{
${ }^{13}$ SILVA, Edgar Neves da. Contribuição de Melhoria. In: MARTINS, Ives Gandra da Silva (Coord.). Curso de Direito Tributário. 13. ed. São Paulo: Saraiva, 2011. P. 1069 e 1070

${ }^{14}$ SABBAG, Eduardo. Manual de Direito Tributário. 3. ed. São Paulo: Saraiva, 2011. P. 462.

${ }^{15}$ SABBAG, Eduardo. Manual de Direito Tributário. 3. ed. São Paulo: Saraiva, 2011. P. 462.
} 
havendo limites apenas em referência a esta situação, ou seja, se um imóvel valia $\mathrm{R} \$ 100.000,00$ reais antes da realização da obra e após passou a valer $R \$ 110.000,00$ reais, será devido pelo contribuinte em caráter de contribuição de melhoria o valor de $\mathrm{R} \$ 10.000,00$ reais em razão da valorização efetiva auferida pelo imóvel. Da mesma forma o critério meramente baseado na contraprestação do pagamento da quantia monetária de valorização do imóvel, embora simples como no modelo alemão mostra-se de aplicabilidade duvidosa no Brasil. ${ }^{16}$

Por assim dizer, a pura contraprestação do pagamento da valorização imobiliária poderá ser onerosa a ambas as partes. Se for construída uma obra de alto valor, porém de pequena valorização dos imóveis, incorrerá o poder público em gasto excessivo sem o ressarcimento devido a que faz jus a aplicação do tributo. Se de outro modo ocorrer uma obra de simples realização, mas que retorne ao proprietário grande valorização imobiliária poderá o contribuinte arcar com custo muito elevado, até mesmo superior ao valor da obra o que é plenamente vedado pelo ordenamento jurídico tributário nacional, sob pena de transforma-se a contribuição de melhoria em imposto ${ }^{17}$.

Deste modo, tanto um modelo quanto outro, embora aplicáveis à realidade onde se inserem com relativo sucesso, deixam a incerteza se poderiam ser efetivamente aplicados no Brasil, frente as dificuldades monetárias de capacidade contributiva e as peculiaridades de cada modelo no âmbito da instituição do tributo.

\section{TEORIA APLICADA NO BRASIL}

Frente as ideias propostas e demonstradas até aqui, a contribuição de melhoria tem sido aplicada de forma efetiva em vários países pelo mundo, demonstrando ser ferramenta de desenvolvimento urbano e de equidade tributária.

Como visto anteriormente, no modelo alemão, cobra-se a título de contribuição de melhoria o valor do custo total da obra rateado pelos contribuintes

\footnotetext{
${ }^{16}$ SABBAG, Eduardo. Manual de Direito Tributário. 3. ed. São Paulo: Saraiva, 2011. P. 462.

${ }^{17}$ MACHADO, Hugo de Brito. Curso de Direito Tributário. 32. ed. São Paulo: Malheiros, 2011, P.450
} 
beneficiados, já no americano o que cobra-se é o valor efetivo da valorização do imóvel monetariamente de cada contribuinte beneficiado pela obra pública.

No modelo aplicado no Brasil foi adotada uma teoria mista que não se atêm unicamente ao custo total da obra, nem tampouco na valorização auferida pelo imóvel. Na teoria mista o valor pago a título de contribuição de melhoria leva em consideração tanto a valorização do imóvel, quanto o custo total da obra, limitada a cobrança aos valores de ambos, ou seja, não pode o poder público arrecadar do contribuinte valor superior ao custo total da obra, nem maior que a valorização individual do imóvel beneficiado. ${ }^{18}$

Desta forma limita-se o poder de tributar do Estado para que a contribuição de melhoria seja instituída para o ressarcimento do poder público pela realização da obra que gerou a valorização dos imóveis, e não como forma de financiamento das obras públicas ou confisco estatal dos bens do contribuinte.

Aliomar Baleeiro orienta no sentido que:

\begin{abstract}
A contribuição de melhoria oferece matiz próprio e específico: ela não é a contraprestação de um serviço público incorpóreo, mas a recuperação do enriquecimento ganho por um proprietário em virtude de obra pública concreta no local da situação do prédio. Daí a justificação do Tributo pelo princípio do enriquecimento sem causa, peculiar ao Direito Privado. Se o Poder Público, embora agindo no interêsse da coletividade, emprega vultosos fundos desta em obras estritas a certo local, melhorando- o tanto que se observa elevação do valor dos imóveis aí situados, com exclusão de outras causas decorrentes da diligência do proprietário, impõe-se que êste, por elementar princípio de justiça e de moralidade, restitua parte do benefício originado de dinheiro alheio ${ }^{19}$.
\end{abstract}

Assim, é a contribuição de melhoria, tributo baseado no equilíbrio entre o Poder público, os beneficiados pela obra e a sociedade, para que tanto a realização da obra, quanto a instituição do tributo não seja muito onerosa a nenhuma das partes.

\footnotetext{
${ }^{18}$ SABBAG, Eduardo. Manual de Direito Tributário. 3. ed. São Paulo: Saraiva, 2011. P. 463.

${ }^{19}$ BALEEIRO, Aliomar. Direito Tributário Brasileiro. 3. ed. Rio de Janeiro: Forense, 1971. P. 319.
} 


\section{NATUREZA JURÍDICA DA CONSTRIBUIÇÃO DE MELHORIA}

$\mathrm{O}$ art. $4^{\circ}$ do $\mathrm{CTN}^{20}$ determina acerca da natureza jurídica dos tributos que se instituem de acordo com o fato gerador dos mesmos. Os tributos podem ser não vinculados, ou seja, não está vinculado a nenhuma atividade relativa ao sujeito passivo, esse é o caso do Imposto. A taxa de outra banda consiste em tributo vinculado, pois seu fato gerador está ligado a atividade estatal indiretamente vinculada ao contribuinte, assim como a contribuição de melhoria, que se apresenta, da mesma forma, como tributo vinculado ${ }^{21}$.

Geraldo Ataliba escreve a respeito da natureza jurídica da contribuição de melhoria, no seguinte sentido:

De todo o exposto resulta evidente ser a contribuição de melhoria tributo sôbre a mais valia. Sua natureza estrutura e modo de atuação são características dos tributos. (...) Justifica-se êsse procedimento, pela necessidade da existência e atividade do estado ${ }^{22}$.

Pois bem, se vê que, a atividade estatal configura-se como elemento à instituição da contribuição de melhoria, reforçando a ideia de ser um tributo de natureza vinculada. "Isso porque não é dado aos executores da lei apreciar a oportunidade do recurso a determinado tipo de tributo. A atividade de lançamento e arrecadação é vinculada” ${ }^{23}$.

Rubens de Miranda Carvalho diz que "a contribuição de melhoria está intimamente ligada a uma atividade estatal diretamente relacionada com aquele que

\footnotetext{
${ }^{20}$ Art. 4 A natureza jurídica específica do tributo é determinada pelo fato gerador da respectiva obrigação, sendo irrelevantes para qualificá-la:

I - a denominação e demais características formais adotadas pela lei;

II - a destinação legal do produto da sua arrecadação. BRASIL. Lei no 5.172, de 25 de outubro de 1966. Dispõe sobre o Sistema Tributário Nacional e institui normas gerais de direito tributário aplicáveis à União, Estados e Municípios. Disponível em: http://www.planalto.gov.br/ccivil_03/leis/L5172Compilado.htm. Acesso em: 05 jun. 2016.

${ }^{21}$ SABBAG, Eduardo. Manual de Direito Tributário. 3. ed. São Paulo: Saraiva, 2011. P. 453.

${ }^{22}$ NOGUEIRA, José Geraldo Ataliba. Natureza Jurídica da Contribuição de Melhoria. São Paulo: Revista dos Tribunais, 1964. P. 101.

${ }^{23}$ NOGUEIRA, José Geraldo Ataliba. Natureza Jurídica da Contribuição de Melhoria. São Paulo: Revista dos Tribunais, 1964. P. 67.
} 
será o seu sujeito passivo" ${ }^{24}$. Assim, a natureza da contribuição de melhoria é vinculada a determinada atividade estatal que a dê origem, no caso da contribuição de melhoria, refere-se à valorização imobiliária geradora da vinculação tributária, que determina a natureza jurídica do tributo.

\section{FATO GERADOR}

Encontra-se diverso na doutrina o entendimento sob qual seria o fato gerador da contribuição de melhoria. Para a grande maioria dos doutrinadores entre eles Hugo de Brito Machado o fato gerador para a efetivação da cobrança da contribuição de melhoria é a valorização do imóvel beneficiado pela obra pública ${ }^{25}$. Entretanto para outros de uma corrente minoritária encabeçados por Sacha Calmon Navarro Coelho a simples realização da obra pelo poder público autoriza a cobrança do tributo sem que seja necessária a valorização de fato do imóvel. Para ele a valorização imobiliária esta intrínseca a realização da obra não podendo cobrar o poder público por obra que desvalorize o imóvel, por fato, se houver cobrança de contribuição de melhoria haverá valorização ${ }^{26}$.

Neste pensamento baseiam-se os que vislumbram a contribuição de melhoria apenas no prisma constitucional, Sacha Calmon Navarro Coelho cita em seu livro "Com efeito, a Constituição agora fala exclusivamente em "contribuição de melhoria decorrente de obra pública", sem ao menos mencionar a palavra valorização (e o faz corretamente)". ${ }^{27}$ Assim, seria necessário para a validade da cobrança do tributo apenas a efetiva realização da obra pública independente da valorização ou não dos imóveis lindeiros.

Em contraponto salienta Hugo de Brito Machado em seu Curso de Direito Tributário "O fato gerador da contribuição de melhoria é a valorização do imóvel do

\footnotetext{
${ }^{24}$ CARVALHO, Rubens Miranda de. Contribuição de Melhoria e Taxas no Direito Brasileiro. São Paulo: Juarez de Oliveira, 1999. P.50.

${ }^{25}$ MACHADO, Hugo de Brito. Curso de Direito Tributário. 32. ed. São Paulo: Malheiros, 2011. P. 447.

${ }^{26}$ COELHO, Sacha Calmon Navarro. Curso de direito tributário brasileiro. 7. ed. Rio de Janeiro: Forense, 2004. P. 644.

${ }^{27}$ COELHO, Sacha Calmon Navarro. Curso de direito tributário brasileiro. 7. ed. Rio de Janeiro: Forense, 2004. P. 644.
} 
qual o contribuinte é proprietário, ou enfiteuta, desde que essa valorização seja decorrente de obra pública". ${ }^{28}$ Desta forma não há de se cogitar a ideia do fato gerador da contribuição de melhoria embasar-se apenas na realização da obra sem a efetiva valorização imobiliária, como o mesmo cita mais à frente “... há quem cogite da possibilidade de haver contribuição de melhoria independentemente da valorização imobiliária. Seria bastante a obra pública. Isto é um despautério que desmerece qualquer exame". ${ }^{29}$

Geraldo Ataliba embasa este entendimento no sentido de que "a valorização não é mero pressuposto da tributação, e sim seu assento." ${ }^{30}$ Reforçando a ideia de que a valorização imobiliária é elemento básico da contribuição de melhoria, não podendo dela ser afastado.

Bilac Pinto ainda sob a égide da Constituição de 1934, já menciona a necessidade de valorização imobiliária assim como os limites à cobrança como elementos do cerne da contribuição de melhoria:

Contribuição de melhoria é o pagamento obrigatório decretado, exclusivamente ou concorrentemente, pelo Municipio, pelo Estado e pela União, em razão da valorização produzida em imóvel do contribuinte, por obra publica, realizada após sua audiência, e cujo montante não pode ultrapassar nem o custo da obra, nem o valôr do beneficio ${ }^{31}$.

Entretanto estas questões muito se asseveram em razão da redação trazida pela Constituição atual de 1988 em seu Artigo 145, III que diferentemente do Artigo 81 do CTN omite-se no sentido da valorização imobiliária como requisito da instituição do tributo. Trazendo em seu texto literal apenas a expressão "contribuição de melhoria, decorrente de obras públicas"32 dando base aos que questionam a matéria.

${ }^{28}$ MACHADO, Hugo de Brito. Curso de Direito Tributário. 32. ed. São Paulo: Malheiros, 2011, P. 447

${ }^{29}$ MACHADO, Hugo de Brito. Curso de Direito Tributário. 32. ed. São Paulo: Malheiros, 2011, P. 448

${ }^{30}$ NOGUEIRA, José Geraldo Ataliba. Natureza Jurídica da Contribuição de Melhoria. São Paulo: Revista dos Tribunais, 1964. P.107.

${ }_{31}$ PINTO, Bilac. Contribuição de melhoria. Rio de Janeiro: Forense, 1939, P. 07

32 Art. 145, III, Constituição (1988). BRASIL. Constituição Federal, Código Tributário, Código Comercial. 9. ed. Porto Alegre: Verbo Jurídico, 2010. 
Porém a maioria admite que a valorização imobiliária é requisito principal para a instituição da cobrança da contribuição de melhoria sendo o fato gerador que enseja a cobrança do tributo.

O STF manifestou-se no sentido de que a valorização imobiliária é elemento indispensável à cobrança da contribuição de melhoria.

No acórdão que julgou Agravo regimental no Agravo de Instrumento $\mathrm{n}^{\mathrm{o}}$ 694836, decidiram com relatório da Ministra Ellen Gracie, da seguinte maneira:

CONSTITUCIONAL. TRIBUTÁRIO. AGRAVO REGIMENTAL NO AGRAVO DE INSTRUMENTO. CONTRIBUIĈÃO DE MELHORIA. FATO GERADOR: QUANTUM DA VALORIZAÇÃO IMOBILIÁRIA. PRECEDENTES. 1. Esta Corte consolidou o entendimento no sentido de que a contribuição de melhoria incide sobre o quantum da valorização imobiliária. Precedentes. 2. Agravo regimental improvido ${ }^{33}$.

Assim como no Supremo Tribunal Federal, no STJ também encontra-se pacificada a matéria, como pode-se ver em acórdão de relatório do Ministro Benedito Gonçalves:

PROCESSUAL CIVIL E TRIBUTÁRIO. AGRAVO REGIMENTAL NO AGRAVO EM RECURSO ESPECIAL. CONTRIBUIÇÃO DE MELHORIA. BASE DE CÁLCULO. VALORIZAÇÃO IMOBILIÁRIA. ÔNUS DA PROVA. ENTE TRIBUTANTE. SÚMULA 83/STJ. 1. A jurisprudência do STJ é pacífica no sentido de que a contribuição de melhoria é tributo, cujo fato imponível decorre da valorização imobiliária causada pela realização de uma obra pública, cabendo ao ente público o ônus da sua comprovação, a fim de justificar o tributo estipulado ${ }^{34}$.

Neste sentido podemos ver que embora discutido no âmbito doutrinário, encontra-se consolidado nas decisões jurisprudenciais dos órgãos superiores, 0 entendimento que embora omisso no texto constitucional a necessidade da valorização imobiliária para a instituição da contribuição de melhoria. Este requisito

${ }^{33}$ BRASIL. Supremo Tribunal Federal - Al: 694836 SP, Relator: Min. ELLEN GRACIE, Data de Julgamento: 24/11/2009, Segunda Turma, Data de Publicação: DJe-237 DIVULG 17-12-2009 PUBLIC 18-12-2009: Disponível em: http://stf.jusbrasil.com.br/jurisprudencia/6187521/agregno-agravo-deinstrumento-ai-694836-sp. Acesso em: 30 de mai. De 2016.

${ }^{34}$ BRASIL. Superior Tribunal de Justiça - AgRg no AREsp: 406324 PR 2013/0332193-8, Relator: Ministro BENEDITO GONÇALVES, Data de Julgamento: 27/03/2014, T1 - PRIMEIRA TURMA, Data de Publicação: DJe 09/04/2014. Disponível em: http://stj.jusbrasil.com.br/jurisprudencia/152376871/agravo-regimental-no-recurso-especial-agrg-noresp-1303516-rs-2011-0156519-8. Acesso em: 25 de mai. De 2016. 
mantém-se atrelado ao fundamento básico da contribuição de melhoria, independente de expressa determinação Constitucional.

Ricardo Alexandre em seu livro de Direito tributário faz coerente citação a este respeito.

O fato gerador da contribuição de melhoria não é a realização da obra, mas sim sua conseqüência, a valorização imobiliária. A melhoria exigida pela Constituição é segundo o STF, o acréscimo de valor à propriedade imobiliária dos contribuintes, de forma que a base de cálculo do tributo será exatamente o valor acrescido, ou seja, a diferença entre os valores inicial e final do imóvel beneficiado ${ }^{35}$.

Isso posto, percebe-se que é necessária independentemente da situação fática a demonstração da valorização do imóvel beneficiado para a instituição da contribuição de melhoria, no entendimento mais que consolidado da maioria dos Doutrinadores do Superior Tribunal de Justiça e do Supremo Tribunal Federal. Ricardo Alexandre chama atenção para interessante diferença entre valorização e benefício, que por vezes se confunde no debate acerca do cumprimento dessa determinação legal.

Vê-se da seguinte forma "[...] não é todo benefício proporcionado pela obra ao particular que legitima a cobrança da contribuição. A valorização imobiliária é fundamental." Neste sentido verifica-se que benefício e valorização imobiliária não podem se confundir como se fossem a mesma coisa, pode-se considerar como valorização algo que altere o valor real do imóvel, algo que tire o imóvel de um estágio inicial valorativo e o coloque e outro maior ao final da obra pública. Por conseguinte, benefício refere-se a uma melhora da situação do imóvel em relação ao proprietário, podendo ou não estar vinculado a valorização do imóvel. ${ }^{36}$

Num exemplo prático, em entendimento do $\mathrm{STF}^{37}$, já manifestado em razão das despesas oriundas da pavimentação de via pública, se for pavimentação nova

\footnotetext{
${ }^{35}$ ALEXANDRE, Ricardo. Direito Tributário Esquematizado. 4. ed. São Paulo: Método, 2010.P. 73. 36 ALEXANDRE, Ricardo. Direito Tributário Esquematizado. 4. ed. São Paulo: Método, 2010.P. 72

${ }^{37}$ Decisão: Vistos. Município de Tupã interpõe recurso extraordinário, com fundamento na alínea "a"do permissivo constitucional, contra decisão que negou provimento aos embargos infringentes, consignando que: "(...) No caso vertente, é pressuposto do tributo, portanto, que o imóvel beneficiado tenha seu valor aumentado em razão da obra. No entanto, o bem pertencente ao contribuinte, conforme restou provado no autos, já era servido por pavimentação asfáltica, de forma que o mero reparo, ainda que sob a forma de recapeamento, não é capaz de trazer ao imóvel nem uma sensível valorização. Nenhum imóvel vale mais ou menos porque o asfalto passa em sua frente está em bom
} 
que gerar valorização dos imóveis beneficiados, poderá ser instituída a cobrança da contribuição de melhoria. Entretanto se esta pavimentação for de recapeamento da via pública já asfaltada, refuta-se apenas serviço de manutenção ou conservação, não dando razão a cobrança do tributo, deste modo ocorrerá apenas benefício aos proprietários e não valorização dos seus imóveis ${ }^{38}$.

De uma forma ou de outra, entende-se como desmerecedora de análise mais aprofundada a ideia de instituição da contribuição de melhoria sem a efetiva demonstração da valorização imobiliária, apenas com base na falta de previsão legal trazida no texto constitucional da Constituição de 1988.

Rubens Miranda de Carvalho nos diz conceito válido e até previsto em nossa Carta Magna atual, da norma constitucional ser genérica, não abrangendo um todo completo em determinação legal das formas específicas de cada norma enunciada. Vê-se que "o texto constitucional pode ser genérico, desde que trace um quadro mínimo delineador do fato gerador de cada tributo, deixando para a norma complementar (...) as minúcias da sua definição"39.

Por assim ver, cabem as normas complementares de fato, complementar as lacunas deixadas pelo texto constitucional e, é dessa forma que se apresenta, como norma infraconstitucional as redações dispostas no CTN no art. $81^{40}$ e também no Decreto-Lei 195/67 $7^{41}$ que determinam expressamente a necessidade da

ou mau estado de conservação. Com efeito, não havendo sequer sensível valorização do bem, é manifestamente ilegal a cobrança do tributo, mormente na forma que the é peculiar, ou seja, contribuição de melhoria.(...) BRASIL. Supremo Tribunal Federal - RE: 704954 SP, Relator: Min. DIAS TOFFOLI, Data de Julgamento: 17/12/2012, Data de Publicação: DJe-023 DIVULG 01/02/2013 PUBLIC 04/02/2013. Disponível em: http://stf.jusbrasil.com.br/jurisprudencia/23041140/recursoextraordinario-re-704954-sp-stf. Acesso em: 25 de mai. De 2016.

${ }^{38}$ ALEXANDRE, Ricardo. Direito Tributário Esquematizado. 4. ed. São Paulo: Método, 2010.P. 73 e 74.

${ }^{39}$ CARVALHO, Rubens Miranda de. Contribuição de Melhoria e Taxas no Direito Brasileiro. São Paulo: Juarez de Oliveira, 1999. P.65.

${ }^{40}$ Art. 81. A contribuição de melhoria cobrada pela União, pelos Estados, pelo Distrito Federal ou pelos Municípios, no âmbito de suas respectivas atribuições, é instituída para fazer face ao custo de obras públicas de que decorra valorização imobiliária, tendo como limite total a despesa realizada e como limite individual o acréscimo de valor que da obra resultar para cada imóvel beneficiado. BRASIL. Lei no 5.172, de 25 de outubro de 1966. Dispõe sobre o Sistema Tributário Nacional e institui normas gerais de direito tributário aplicáveis à União, Estados e Municípios. Disponível em: http://www.planalto.gov.br/ccivil_03/leis/L5172Compilado.htm. Acesso em: 05 jun. 2016

41 Art 1ㅇ A Contribuição de Melhoria, prevista na Constituição Federal tem como fato gerador o acréscimo do valor do imóvel localizado nas áreas beneficiadas direta ou indiretamente por obras públicas. BRASIL. Decreto-Lei № 195, De 24 De Fevereiro De 1967. Dispõe sobre a cobrança da 
demonstração da valorização imobiliária como fato gerador da contribuição de melhoria. Deste modo complementando o texto constitucional de forma específica e regulando a matéria concernente ao seu objeto de regulamentação.

\section{NECESSIDADE DE LEI ESPECÍFICA PARA CADA OBRA}

Preceituam o art. 82 do CTN, assim como o art. 5ํ do Decreto-Lei 195/67, os requisitos mínimos para a cobrança da contribuição de melhoria. Nos supracitados artigos, questão que envolve questionamento doutrinário e debates jurisprudências, refere-se a necessidade de publicação de lei específica anterior a cada obra que se vá realizar para posterior cobrança do tributo.

Neste entendimento o Tribunal do Rio Grande do Sul manifestou-se da seguinte forma:

APELAÇÃO CÍVEL. DIREITO TRIBUTÁRIO. AÇÃO DECLARATÓRIA. CONTRIBUIÇÃO DE MELHORIA. EXIGÊNCIA DO TRIBUTO COM OBSERVÂNCIA DOS REQUISITOS LEGAIS. CTN, ARTS. $81 \mathrm{E} 82$, E DECRETO-LEI $195 / 67$. A contribuição de melhoria tem como fato gerador o acréscimo do valor do imóvel nas áreas beneficiadas, direta ou indiretamente, por obras públicas (art. 1ํ do Decreto-Lei ํㅜ 195 /67). Sua exigência pressupõe a observância dos requisitos mínimos previstos na legislação referida, para o procedimento de lançamento e cobrança. Desnecessidade de lei específica para cada obra. Possibilidade de edital único após a conclusão da obra ${ }^{42}$.

O mesmo Tribunal gaúcho em outra decisão demonstra entendimento contrário:

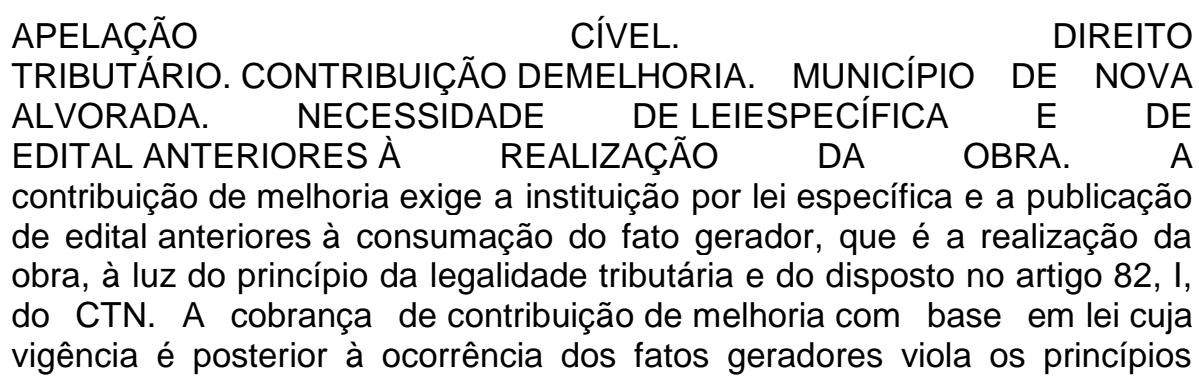

Contribuição de Melhoria. Disponível em < http://www.planalto.gov.br/ccivil_03/decretolei/del0195.htm>. Acesso em: 26 jun. 2016.

${ }^{42}$ BRASIL. Tribunal de justiça/RS. Apelação Cível № 70053333704, Primeira Câmara Cível, Tribunal de Justiça do RS, Relator: Luiz Felipe Silveira Difini, Julgado em 24/04/2013, Data da publicação: 06/05/2013. Disponível em: http://tj-rs.jusbrasil.com.br/jurisprudencia/112852104/apelacao-civel-ac70053333704-rs. Acesso em: 01 de jun. de 2016. 
constitucionais da irretroatividade e da anterioridade. Inteligência do artigo 150, III, a, da CF. Precedentes do STJ e desta Corte ${ }^{43}$.

É percebido que o entendimento não encontra-se plenamente pacificado, restando debates acerca da real obrigação trazida nos textos legais. Se há necessidade de lei específica para cada obra que ensejará a cobrança da contribuição de melhoria ou se deverá haver lei regulamentadora, municipal, estadual ou federal, específica, única para a aplicação da contribuição de melhoria.

O STJ manifestou no sentido de não haver tal necessidade de publicação de lei específica para cada obra realizada, desde que respeitados os requisitos do art. 82 publicados previamente no edital.

TRIBUTÁRIO. RECURSO ESPECIAL. CONTRIBUIC̄ÃO DE MELHORIA. LEI ESPECÍFICA PARA CADA OBRA. NECESSIDADE. AUSÊNCIA DE PUBLICAÇÃO DE DOIS EDITAIS. AUSÊNCIA DE NOTIFICAÇÃO PRÉVIA DO LANÇAMENTO. SÚMULA 07 DO STJ.(...)1. A contribuição de melhoria é tributo cujo fato imponível decorre da valorização imobiliária que se segue a uma obra pública, ressoando inequívoca a necessidade de sua instituição por lei específica, emanada do Poder Público construtor, obra por obra, nos termos do art. 150 , I, da CF/88 c/c art. 82 do CTN, uma vez que a legalidade estrita é incompatível com qualquer cláusula genérica de tributação. (Precedentes: REsp 739.342/RS, Rel. Ministro FRANCISCO FALCÃO, PRIMEIRA TURMA, julgado em 04/04/2006, DJ 04/05/2006; REsp 444.873/RS, Rel. Ministro CASTRO MEIRA, SEGUNDA TURMA, julgado em 23/08/2005, DJ 03/10/2005) 2. In casu, consoante dessume-se do voto condutor do acórdão recorrido, o entendimento esposado pelo Tribunal a quo diverge da jurisprudência dominante nesta Corte Superior, in verbis: "Inicialmente, destaco que entendo não ser necessária a existência de uma lei específica, obra por obra, para a instituição e cobrança de contribuição de melhoria. Nessa perspectiva, tenho que o Município apelado logrou comprovar o atendimento ao princípio da legalidade tributária (art. 150, I, da CF/88), ao acostar ao presente feito, a Lei Municipal no 286/96 de fl. 151, a qual autoriza o Poder Executivo a realização de obras de pavimentação asfáltica nas ruas no perímetro urbano, o que abarca a hipótese sob exame."(...) concerne à publicação de edital de realização e conclusão da obra e notificação/intimação do apelante, visto que restaram ambos comprovados nos autos às fls. 62 e 100/101, bem como à fl.45, bastantes para preencher os referidos requisitos previstos no CTN, art. 82, I, e Decreto-Lei n.ำ 195/67, art. 50.."44.

${ }^{43}$ BRASIL. Tribunal de Justiça/RS. Apelação Cível № 70056159213, Segunda Câmara Cível, Tribunal de Justiça do RS, Relator: Almir Porto da Rocha Filho, Julgado em 09/10/2013, Data da publicação: 15/10/2013. Disponível em: http://tjrs.jusbrasil.com.br/jurisprudencia/113486165/apelacao-civel-ac-70056159213-rs. Acesso em: 05 de jun. de 2016.

${ }^{44}$ BRASIL. Superior Tribunal de Justiça - REsp: 927846 RS 2007/0038580-3, Relator: Ministro LUIZ FUX, Data de Julgamento: 03/08/2010, T1 - PRIMEIRA TURMA, Data de Publicação: DJe 
Em razão da publicação prévia do edital com os requisitos apresentados pelo art. 82, CTN, Eduardo Sabbag nos orienta com análise de entendimento do STF de que a publicação necessita ser anterior a cobrança, mas não a obra.

CONTRIBUICAO DE MELHORIA. (...). OFENSA AO ART. 18, II, DA CONSTITUICAO FEDERAL. DIVERGENCIA JURISPRUDENCIAL QUANTO A APLICACAO DO ART. 5० DO DECRETO-LEI N. 195/67. Prevalência da tese de que a publicação previa do edital previsto no mencionado dispositivo e necessária para a cobrança da contribuição de melhoria, e não para a realização da obra. Recurso extraordinário conhecido e provido ${ }^{45}$.

Deste modo pode-se ver que os requisitos do art. 82 do CTN, devem ser publicados por edital aos contribuintes anteriormente ao lançamento da cobrança do tributo, e não da realização da obra. No que tange a lei específica para cada obra, embora divergente entende-se de forma dominante na Corte do STJ, que não é necessária publicação de lei específica para cada obra, desde que assegurados os requisitos previstos no art. 82 , CTN.

\section{LIMITES (valorização individual X custo total)}

O Art. $81^{46}$ do Código Tributário Nacional descreve em sua redação, expressamente, os limites à cobrança da contribuição de melhoria, no sistema adotado pelo ordenamento jurídico tributário brasileiro, existem dois limites a essa cobrança o individual e o global. O limite global tem-se pelo valor total da obra, não podendo os recursos alcançados pela cobrança do tributo exacerbá-lo, ou seja, não pode o valor auferido pelo pagamento dos contribuintes, ultrapassar o custo total da

20/08/2010. Disponível em: http://stj.jusbrasil.com.br/jurisprudencia/15955623/recurso-especial-resp927846-rs-2007-0038580-3. Acesso em: 15 de jun. de 2016.

${ }^{45}$ BRASIL. Supremo Tribunal Federal. RE 98.408/PR, Relator: Ministro. SOARES MUNOZ, Data do julgamento. 19/04/1983, T1 - PRIMEIRA TURMA. In. SABBAG, Eduardo. Manual de Direito Tributário. 3. ed. São Paulo: Saraiva, 2011. P. 470.

${ }^{46}$ Art. 81. A contribuição de melhoria cobrada pela União, pelos Estados, pelo Distrito Federal ou pelos Municípios, no âmbito de suas respectivas atribuições, é instituída para fazer face ao custo de obras públicas de que decorra valorização imobiliária, tendo como limite total a despesa realizada e como limite individual o acréscimo de valor que da obra resultar para cada imóvel beneficiado. BRASIL. Lei no 5.172, de 25 de outubro de 1966. Dispõe sobre o Sistema Tributário Nacional e institui normas gerais de direito tributário aplicáveis à União, Estados e Municípios. Disponível em: http://www.planalto.gov.br/ccivil_03/leis/L5172Compilado.htm. Acesso em: 05 jun. 2016. 
obra. Isso se faz necessário para evitar-se que o poder público lucre com a realização da obra pública. Cabe a contribuição de melhoria ressarcir ao erário público em parte ou num todo o custo da obra e não financiá-la previamente ou arrecadar fundos para sua posterior realização ${ }^{47}$.

Já no que tange o limite individual refere-se ao fato do proprietário do imóvel beneficiado não pagar valor maior que a valorização auferida ao imóvel com a realização da obra, sendo assim limita-se o pagamento em caráter individual até o valor máximo da valorização do imóvel após a realização da obra pública e de natureza global até o teto do custo total da obra ${ }^{48}$.

Esses limites se fazem necessários para garantir que o proprietário do imóvel não pague mais do que deve ao poder público. Lembra-se que a contribuição de melhoria visa o ressarcimento ao erário de gastos decorrentes de obras públicas financiadas com dinheiro de todos e que valorizou apenas determinados imóveis. E não para o prévio financiamento da obra pública pelos proprietários dos imóveis por ela posteriormente beneficiados ${ }^{49}$.

Deste modo os limites são importantes para garantir a validade da cobrança da contribuição de melhoria, porém os limitadores previstos no art. 81 do Código Tributário Nacional podem ser empecilhos para a devida cobrança do tributo.

Diz Hugo de Brito Machado em seu curso de direito tributário:

O valor da contribuição a ser paga por cada contribuinte não poderá ser superior ao acréscimo de valor do imóvel respectivo, nem o total das contribuições arrecadadas poderá ser superior ao custo da obra (CTN, art. 81).

Considerando que o montante da valorização de cada imóvel não é de fácil determinação, tem-se que admitir possa a autoridade administrativa fazer um arbitramento deste. Mas é intocável o art. 148 do CTN, podendo o contribuinte, assim, impugnar o arbitramento ${ }^{50}$.

\footnotetext{
${ }^{47}$ MACHADO SEGUNDO, Hugo de Brito. Código Tributário Nacional, Anotações à Constituição, ao Código Tributário Nacional e às Leis complementares 87/1996 e 116/2003, 2. ed. São Paulo: Editora Atlas, 2009. P. 191.

${ }^{48}$ MACHADO SEGUNDO, Hugo de Brito. Código Tributário Nacional, Anotações à Constituição, ao Código Tributário Nacional e às Leis complementares 87/1996 e 116/2003, 2ed. São Paulo: Editora Atlas, 2009. P. 191.

${ }^{49}$ MACHADO SEGUNDO, Hugo de Brito. Código Tributário Nacional, Anotações à Constituição, ao Código Tributário Nacional e às Leis complementares 87/1996 e 116/2003, 2. ed. São Paulo: Editora Atlas, 2009. P. 191.

50 MACHADO, Hugo de Brito. Curso de Direito Tributário. 32. ed. São Paulo: Malheiros, 2011. P. 450.
} 
Assim, entende-se que é de difícil demonstração pelo poder público a valorização efetiva do imóvel decorrida da realização da obra pública. Destarte o valor por vezes informado pode ser impugnado pelo contribuinte que se sentir lesado o que ocorre em muitos casos ${ }^{51}$.

A demonstração da real valorização do imóvel se faz requisito indispensável para a instituição da contribuição de melhoria, entretanto atende-se como critério subjetivo muito amplo e de difícil demonstração fática.

Para Edgar Neves da Silva nas compilações reunidas por Ives Gandra da Silva Martins, diz-se, "poderiam instituir a contribuição de melhoria, tomando por exemplo, a forma alemã, muito mais simples e quem sabe de fácil aclimatação à nossa realidade" ${ }^{25}$. Neste breve comentário Edgar Neves da Silva critica a complexidade da aplicação da contribuição de melhoria tanto na questão dos limites e da demonstração da valorização imobiliária, quanto na razão da delimitação da zona beneficiada pela obra. É previsto em nosso ordenamento jurídico a cobrança da contribuição de melhoria dos proprietários beneficiados direta ou indiretamente pela realização da obra desde que comprovada a valorização dos imóveis, o que de fato se torna muito difícil quando o imóvel e indiretamente beneficiado. A falta da visualização da obra por vezes impede a instituição do tributo, sendo razão de impugnação pelos proprietários indiretamente beneficiados, restando aos diretamente beneficiados à reparação pela contribuição de melhoria ${ }^{53}$.

O modelo alemão por Edgar Neves da Silva citado revela uma teoria diferente à adotada no Brasil quanto ao limite da cobrança da contribuição de melhoria por parte do poder público. No modelo alemão não há limite individual apenas global onde o valor total do custo da obra é rateado pelos proprietários beneficiados pela obra pública. Não é necessário informar o quantum valorativo dos imóveis apenas que houve valorização imobiliária naquelas propriedades decorrentes da realização

${ }^{51}$ FABRETTI, Láudio Camargo. Código Tributário Nacional Comentado. 8. ed. São Paulo: Atlas, 2008. P. 114.

52 SILVA, Edgar Neves da. Contribuição de Melhoria. In: MARTINS, Ives Gandra da Silva (Coord.). Curso de Direito Tributário. 13. ed. São Paulo: Saraiva, 2011. P. 1077.

${ }^{53}$ SILVA, Edgar Neves da. Contribuição de Melhoria. In: MARTINS, Ives Gandra da Silva (Coord.). Curso de Direito Tributário. 13. ed. São Paulo: Saraiva, 2011. P. 1081. 
da obra pública e delimitar a zona das propriedades beneficiadas pela obra para nelas incidirem a cobrança do tributo ${ }^{54}$.

Neste modelo chegar ao valor final do cálculo de quanto deve pagar cada contribuinte é muito mais simples tendo-se como base apenas o custo total da obra dividido entre os beneficiados, sendo este critério muito mais objetivo que o aplicado no Brasil.

Todavia em países próximos ao Brasil como Peru e Colômbia é utilizado modelo muito semelhante ao nosso tendo limite a cobrança da contribuição de melhoria de caráter individual e global. Porém nesses países há sucesso na aplicação de tal tributo frente aos esforços do governo desde a escolha da obra até a cobrança efetiva da contribuição, fato que não ocorre no Brasil ${ }^{55}$.

Outra situação que para muitos doutrinadores dificulta a devida instituição e cobrança da contribuição de melhoria seriam os requisitos previstos no art. 82 do CTN. No referido artigo encontram-se os requisitos necessários para a devida instituição e cobrança da contribuição de melhoria ${ }^{56}$.

\footnotetext{
${ }^{54}$ SABBAG, Eduardo. Manual de Direito Tributário. 3. ed. São Paulo: Saraiva, 2011. P. 461.

${ }^{55}$ SILVA, Edgar Neves da. Contribuição de Melhoria. In: MARTINS, Ives Gandra da Silva (Coord.). Curso de Direito Tributário. 13. ed. São Paulo: Saraiva, 2011. P. 1070.

${ }^{56}$ Art. 82. A lei relativa à contribuição de melhoria observará os seguintes requisitos mínimos:

I - publicação prévia dos seguintes elementos:

a) memorial descritivo do projeto;

b) orçamento do custo da obra;

c) determinação da parcela do custo da obra a ser financiada pela contribuição;

d) delimitação da zona beneficiada;

e) determinação do fator de absorção do benefício da valorização para toda a zona ou para cada uma das áreas diferenciadas, nela contidas;

II - fixação de prazo não inferior a 30 (trinta) dias, para impugnação pelos interessados, de qualquer dos elementos referidos no inciso anterior;

III - regulamentação do processo administrativo de instrução e julgamento da impugnação a que se refere o inciso anterior, sem prejuízo da sua apreciação judicial.

$\S 1^{\circ}$ A contribuição relativa a cada imóvel será determinada pelo rateio da parcela do custo da obra a que se refere a alínea $\mathrm{c}$, do inciso I, pelos imóveis situados na zona beneficiada em função dos respectivos fatores individuais de valorização.

$\S 2^{\circ}$ Por ocasião do respectivo lançamento, cada contribuinte deverá ser notificado do montante da contribuição, da forma e dos prazos de seu pagamento e dos elementos que integram o respectivo cálculo. BRASIL. Lei no 5.172, de 25 de outubro de 1966. Dispõe sobre o Sistema Tributário Nacional e institui normas gerais de direito tributário aplicáveis à União, Estados e Municípios. Disponível em:

http://www.planalto.gov.br/ccivil_03/leis/L5172Compilado.htm. Acesso em: 05 jun. 2016.
} 


\section{FATORES SOCIAIS E POLÍTICOS}

Para Hugo de Brito Machado Segundo, um dos grandes empecilhos a cobrança da contribuição de melhoria seria a descrição do orçamento da obra previsto no art. 82 , do CTN. Sabe-se que não interessa ao poder público a divulgação de tal valor, podendo como o próprio artigo autoriza, o proprietário notificado a pagar o tributo, impugnar os valores tanto da obra, quanto do que de fato the é cobrado, demonstrando por vezes os possíveis superfaturamento das obras públicas. ${ }^{57}$

Em uma realidade onde para tudo se quer dar um "jeitinho brasileiro" a formalidade prevista no artigo 82 , do CTN e a transparência necessária para sua efetiva aplicação, não condizem com o comportamento social e político nacional.

O professor Eduardo Sabbag também preceitua que o disposto no art. 82 do CTN, trás dificuldades a cobrança da contribuição de melhoria frente ao desinteresse dos gestores públicos em demonstrar transparência, na realização das obras:

É inegável que a ampla publicação do orçamento da obra e a homenagem ao direito de o contribuinte impugná-lo traduzem-se em verdadeiros incômodos aos maus administradores públicos... E de conhecimento publico que muitas obras públicas são contratadas por valores inauditamente vultosos, superiores aos que o mercado impõe, o que leva a Administração e as empreiteiras a serem as primeiras a pretender escamotear os dados de que dispõem ${ }^{58}$.

Essas dificuldades justificam a inaplicabilidade do tributo, posto que decorrem de interesses particulares dos administradores públicos em beneficiarem-se com o superfaturamento da obra ou com a própria valorização dos imóveis para si, ou para terceiros ${ }^{59}$.

\footnotetext{
${ }^{57}$ MACHADO SEGUNDO, Hugo de Brito. Código Tributário Nacional, Anotações à Constituição, ao Código Tributário Nacional e às Leis complementares 87/1996 e 116/2003, 2. ed. São Paulo: Editora Atlas, 2009. P. 193.

${ }^{58}$ SABBAG, Eduardo. Manual de Direito Tributário. 3. ed. São Paulo: Saraiva, 2011. P. 470.

${ }^{59}$ MACHADO, Hugo de Brito. Curso de Direito Tributário. 32. ed. São Paulo, Malheiros: 2011. P. 453 e 454.
} 


\title{
10 CAPACIDADE CONTRIBUTIVA
}

Outra questão pouco discutida entre a doutrina, mas de grande relevância quando levamos em consideração a vigência dos dispositivos do Decreto-Lei 195/67, refere-se ao disposto no art. 12 do supracitado Decreto-Lei que segue: "Art 12. A Contribuição de Melhoria será paga pelo contribuinte da forma que a sua parcela anual não exceda a 3\% (três por cento) do maior valor fiscal do seu imóvel, atualizado à época da cobrança."

Em análise trazida por Maurício Dalri Timm do Valle e Carlos Renato Cunha no Código anotado organizado pela OAB do Paraná, os autores fazem relevante comentário acerca do dispositivo legal:

\begin{abstract}
Para alguns, esta seria a alíquota permitida para a contribuição de melhoria. Parece-nos, contudo, que referida previsão se assemelha mais a um outro limitador do valor da cobrança, além do custo da obra, para atendimento da Capacidade Contributiva, em que a parcela anual não exceda a $3 \%$ (três por cento) do valor venal do imóvel, não significando que este seja o limite total do valor a ser lançado, que pode vir a ser divido para pagamento em outros exercícios ${ }^{60}$.
\end{abstract}

Neste mesmo sentido julgou o Tribunal de Justiça do Estado de São Paulo em apelação:

Ação anulatória de lançamento fiscal com pedido cumulado de repetição de indébito. Contribuição de melhoria. Excedência do limite previsto no artigo 12 do Decreto-lei 195/67. Fato gerador. Valorização do imóvel. Impossibilidade de cobrança com base no custo da obra pública. Inobservância do estatuído nos artigos 81 e 82 do Código Tributário Nacional. Recurso denegado ${ }^{61}$.

No referido julgamento o emérito Relator Geraldo Xavier fundamenta seu entendimento acerca da matéria da seguinte maneira;

\footnotetext{
${ }^{60}$ VALLE, Maurício Dalri Timm do; CUNHA, Carlos Renato. in: GRILLO, Fábio Artigas; SILVA, Roque Sérgio D'Andrea Ribeiro da (Coord). Código Tributário Nacional, anotado. Escola Superior da Advocacia. Seccional OAB/PR: 2014.P. 227

61 BRASIL. Tribunal de Justiça/SP - APL: 03896021720098260000 SP 0389602-17.2009.8.26.0000, Relator: Geraldo Xavier, Data de Julgamento: 11/04/2013, 14르 Câmara de Direito Público, Data de Publicação: 30/04/2013. Disponível em: sp.jusbrasil.com.br/jurisprudencia/205099540/apelacao-apl-187381720098260068-sp-00187381720098260068/inteiro-teor-205099553. Acesso em: 30 de mai. De 2016.
} 
[...] o artigo 12 do Decreto-lei 195/67 estabelece o limite de cada prestação anual em que dividida a contribuição de melhoria em $3 \%$ (três por cento) do valor venal do bem à época da cobrança. E o documento de folhas 78/87 indica desrespeitado tal limite ${ }^{62}$.

Pode-se ver que o limite, por assim dizer, previsto no art. 12 do Decreto-Lei 195/67 ressalva ao contribuinte a manutenção da sua capacidade contributiva, princípio básico do Direito Tributário. Não sendo assim imposto ao contribuinte valor a título de contribuição de melhoria maior do que ele possa pagar. Não quer dizer que o contribuinte não deva pagar a contribuição de melhoria na totalidade do lançamento do tributo, mas a regulação prevista no art. 12 do Decreto-Lei 195/67 flexibiliza a cobrança da contribuição de melhoria, ressalvando que o contribuinte possa pagar o tributo exigido dentro de sua capacidade contributiva.

Não se comunga à ideia apresentada por Rubens Miranda de Carvalho acerca deste tema no que tange a capacidade contributiva, refere-se o egrégio doutrinador:

Pode bem ocorrer, entretanto que o valor da contribuição de melhoria a ser cobrado de um determinado sujeito passivo, embora contido no limite individual legalmente permitido, não esteja dentro das possibilidades financeiras daquele sujeito passivo. (...) por isso que, não tendo como pagar o valor que lhe seja cobrado a título de contribuição de melhoria, passa o sujeito passivo a correr o risco de ver sua propriedade excutida ${ }^{63}$.

Por óbvio a cobrança da contribuição de melhoria deverá interpor uma vontade compulsória do Poder Público na cobrança do tributo, mas deverá como em qualquer tributo regularmente reconhecido em nosso sistema tributário, resguardase a capacidade para contribuir de cada contribuinte.

Não poderá admitir-se que o dever de contribuir suprima a possibilidade de cada contribuinte cumprir com suas obrigações tributárias. Hugo de Brito Machado salienta a necessidade de observar a capacidade contributiva de cada contribuinte:

62 BRASIL. Tribunal de Justiça/SP - APL: 03896021720098260000 SP 0389602-17.2009.8.26.0000 Relator: Geraldo Xavier, Data de Julgamento: 11/04/2013, 14 Câmara de Direito Público, Data de Publicação: 30/04/2013. Disponível em: sp.jusbrasil.com.br/jurisprudencia/205099540/apelacao-apl-187381720098260068-sp-0018738-

1720098260068/inteiro-teor-205099553. Acesso em: 30 de mai. De 2016.

${ }^{63}$ CARVALHO, Rubens Miranda de. Contribuição de Melhoria e Taxas no Direito Brasileiro. São Paulo: Juarez de Oliveira, 1999. P. 88. 
Ao nosso ver o princípio da capacidade contributiva [...] diz respeito aos tributos em geral [...] Aliás, é esse princípio que justifica a isenção de certas taxas, e até da contribuição de melhoria, em situações nas quais é evidente a inexistência de capacidade contributiva daquele de quem teria de ser o tributo cobrado ${ }^{64}$.

Neste entendimento, ao analisar o art. 12 do Decreto-Lei 195/67, não se tem a pretensão de equipará-lo aos limites basilares e necessários para a devida aplicação da contribuição de melhoria, Custo total X Limite individual. Porém visase ressalvar a observância de princípio legal e doutrinário, de garantir ao contribuinte que a contribuição de melhoria, de fato traga alguma melhoria e não com que o mesmo venha a se desfazer de seu bem para arcar com os encargos tributários.

\section{OMISSÃO CONSTITUCIONAL AO LIMITE GLOBAL}

A contribuição de melhoria encontra-se amparada pela Constituição Federal de 1988 em seu art. 145, inciso III, na redação dada ao artigo segundo a maioria doutrinária omite-se o texto constitucional em relação a delimitar o limite global para a cobrança do tributo. Assim como também deixa lacuna no que se refere à necessidade ou não da valorização imobiliária como fato gerador da instituição do tributo. ${ }^{65}$

Dispõe o referido artigo 145: "A União, os Estados, o Distrito Federal e os Municípios poderão instituir os seguintes tributos: III - contribuição de melhoria, decorrente de obras públicas." Diz Alexandre Rossato Ávila "[...] a doutrina é divergente quanto ao limite total, ou seja, se a contribuição de melhoria estaria limitada pelo custo despendido pelo poder público com a realização da obra. ${ }^{66 "}$

Mais a frente em seu trabalho Rossato Ávila explica melhor a razão da divergência doutrinária e sua relação com a Constituição Federal, diz o emérito doutrinador que "A divergência ocorre porque no sistema constitucional anterior o

\footnotetext{
${ }^{64}$ MACHADO, Hugo de Brito. Curso de Direito Tributário. 32. ed. São Paulo, Malheiros: 2011. P. 39.

${ }^{65}$ AMARO, Luciano. Direito Tributário Brasileiro. 18. ed. São Paulo: Saraiva, 2012. P. 69 e 70.

${ }^{66}$ ÁVILA, Alexandre Rossato. Curso de Direito Tributário. 6. ed. Porto Alegre: Verbo Jurídico, 2011. P.115.
} 
total arrecadado não poderia superar a despesa realizada." (CF/69, art. 18, II) ${ }^{67}$. Desta forma a constituição Federal presente de 1988 não trouxe nenhuma referência ao limite global ou total à cobrança da contribuição de melhoria. Nem mesmo a necessidade da efetiva demonstração da valorização dos imóveis beneficiados, deixando margem aos que defendem a exacerbação do custo total da obra pelo valor arrecadado, assim como a instituição da contribuição de melhoria apenas pela realização da obra pública.

Presente nos regramentos previstos na Constituição Federal desde 1934 a contribuição de melhoria, exceto quando não prevista na Constituição de 1937. Sempre se apresentou literalmente no corpo normativo a valorização dos imóveis beneficiados como escopo para a instituição da contribuição de melhoria.

Determinava o artigo 124 da Constituição Federal de 1934.

"Art. 124 - Provada a valorização do imóvel por motivo de obras públicas, a administração, que as tiver efetuado, poderá cobrar dos beneficiados contribuição de melhoria."

Na Constituição de 1946 instituiu-se novamente o tributo esquecido pela sua antecessora de 1937.

“Art. 30 - Compete à União, aos Estados, ao Distrito Federal e aos Municípios cobrar: I - contribuição de melhoria, quando se verificar valorização do imóvel, em consequência de obras públicas."

Em 1967 na Constituição Federal que antecedeu a Carta Magna de 1988, também foi mencionada no texto constitucional a necessidade da valorização imobiliária como requisito à cobrança da contribuição de melhoria.

"Art. 19 - Compete à União, aos Estados, ao Distrito Federal e aos Municípios arrecadar: III - contribuição de melhoria dos proprietários de imóveis valorizados pelas obras públicas que os beneficiaram."

Até mesmo a emenda constitucional no 1, de 17 de outubro de 1969, entendida como tendo força legislativa de Constituição, fez menção a valorização

${ }^{67}$ ÁVILA, Alexandre Rossato. Curso de Direito Tributário. 6. ed. Porto Alegre: Verbo Jurídico, 2011. P. 115. 
imobiliária como elemento primordial à contribuição de melhoria, assim como citou a necessidade de respeitar os limites total e individual da mesma.

"Art. 18. Além dos impostos previstos nesta Constituição, compete à União, aos Estados, ao Distrito Federal e aos Municípios instituir: II - contribuição de melhoria, arrecadada dos proprietários de imóveis valorizados por obras públicas, que terá como limite total a despesa realizada e como limite individual o acréscimo de valor que da obra resultar para cada imóvel beneficiado."

Pode-se ver que o texto constitucional, sempre trouxe a necessidade da demonstração da valorização imobiliária como requisito à implementação da contribuição de melhoria. Mesmo sendo silente a Constituição Federal de 1988 entende-se que a mesma formulou-se como real preceito constitucional regrando o dispositivo normativo de forma genérica, deixando à lei complementar, sua efetiva complementação legal ${ }^{68}$.

Neste sentido há precedentes tanto no Superior Tribunal de Justiça ${ }^{69}$, quanto no Supremo Tribunal Federal ${ }^{70}$ de que os limites previstos pelo art. 81 do CTN,

\footnotetext{
${ }^{68}$ ALEXANDRE, Ricardo. Direito Tributário Esquematizado. 4. ed. São Paulo: Método, 2010. P. 75. ${ }^{69}$ PROCESSUAL CIVIL E TRIBUTÁRIO. RECURSO ESPECIAL. MANDADO DE SEGURANÇA. CONTRIBUIÇÃO DE MELHORIA. BASE DE CÁLCULO. VALORIZAÇÃO IMOBILIÁRIA. INDIVIDUALIZAÇÃO. ARTIGOS 81 E 82 DO CÓDIGO TRIBUTÁRIO NACIONAL. BRASIL. Superior Tribunal de Justiça - REsp: 147094 PR 1997/0062530-3, Relator: Ministro BENEDITO GONÇALVES, Data de Julgamento: 15/02/2011, T1 - PRIMEIRA TURMA, Data de Publicação: DJe 21/03/2011. Disponível em: http://stj.jusbrasil.com.br/jurisprudencia/18674105/recurso-especial-resp-147094-pr1997-0062530-3. Acesso em: 12 de mai. De 2016.

${ }^{70}$ DECISÃO AGRAVO DE INSTRUMENTO. TRIBUTÁRIO. CONTRIBUIÇÃO DE MELHORIA . BASE DE CÁLCULO : CUSTO DA OBRA. ILEGALIDADE. JURISPRUDÊNCIA DESTE SUPREMO TRIBUNAL. AGRAVO AO QUAL SE NEGA SEGUIMENTO. Relatório 1. Agravo de instrumento contra decisão que não admitiu recurso extraordinário, interposto com base no art. 102, inc. III, alínea a, da Constituição da República. 2. O Tribunal de Justiça do Rio Grande do Sul julgou apelação em ação ordinária, nos termos seguintes: 'TRIBUTÁRIO. CONTRIBUIÇÃO DE MELHORIA. DECRETO-LEI № 195/67. FATO GERADOR. VALORIZAÇÃO DO IMÓVEL. O só fato da obra pública não dá ensejo à cobrança de melhoria. $O$ fato gerador consiste na valorização imobiliária dela decorrente. Ilegalidade da instituição do custo da obra como base de cálculo do tributo. Violação ao Decreto-lei 167/67, que foi recepcionado pela Constituição Federal de 1988. Hipótese em que o tributo foi calculado tendo em conta a testada do imóvel e não a plus valia. Precedentes do STJ. BRASIL. Supremo Tribunal Federal - Al: $\mathbf{7 4 1 6 9 4}$ RS, Relator: CÁRMEN LÚCIA, Data de Julgamento: 03/03/2009, Data de Publicação: DJe-062 DIVULG 31/03/2009 PUBLIC 01/04/2009. Disponível em: http://stf.jusbrasil.com.br/jurisprudencia/3609164/agravo-de-instrumento-ai-741694. Acesso em: 12 de mai. de 2016.
} 
embora anteriores a Constituição Federal vigente, permanecem como base limitadora a arrecadação da contribuição de melhoria ${ }^{71}$.

Rubens Miranda de Carvalho ressalva que embora a Constituição Federal seja silente ao não mencionar em seu texto constitucional os limites, individual e total da contribuição de melhoria como citado em constituições anteriores. Os mesmos encontram-se regulados por norma infraconstitucional complementar no Decreto-Lei 195/67.

[...] o decreto-lei, com a sua eficácia de norma geral de direito tributário complementar da Constituição, estabelece os limites que esta deixou de impor, mas que são ínsitos na natureza da própria contribuição de melhoria"

Assim comungam os que defendem a recepção tanto dos arts. 81 e 82 , do CTN como o teor do Decreto-lei 195/67 pela Constituição Federal de 1988. E que a omissão do texto constitucional em citar explicitamente tanto os limites global ou individual como a necessidade da demonstração da valorização do imóvel para cobrança do tributo refuta-se mero erro de formulação legal que fica suprimido pela vigência das supracitadas leis que regulam a matéria $^{73}$.

\section{CONCLUSÃo}

O presente artigo buscou analisar a contribuição de melhoria, tributo que consiste no ressarcimento aos cofres públicos dos valores gastos na realização de obra pública, da qual restou valorização imobiliária dos imóveis beneficiados pela obra.

Percebe-se que este instituto tributário ainda carece de entendimento e compreensão de seus reais fundamentos pelos doutrinadores que o estudam, e pelos próprios entes públicos que o instituem.

\footnotetext{
${ }^{71}$ ÁVILA, Alexandre Rossato. Curso de Direito Tributário. 6. ed. Porto Alegre: Verbo Jurídico, 2011. P. 115 e 116.

${ }^{72}$ CARVALHO, Rubens Miranda de. Contribuição de Melhoria e Taxas no Direito Brasileiro. São Paulo: Juarez de Oliveira, 1999. P.71.

${ }^{73}$ SILVA, Edgar Neves da. Contribuição de Melhoria. In: MARTINS, Ives Gandra da Silva (Coord.). Curso de Direito Tributário. 13. ed. São Paulo: Saraiva, 2011. P. 1077 e 1078.
} 
Embora os limites aplicados à contribuição de melhoria, estejam pacificados nos tribunais superiores, como elementos estritamente necessários a cobrança do tributo, ainda surgem debates e entendimentos contrários.

Entendimentos estes, que confrontam a matéria equiparando-o a sistemas alienígenas ao brasileiro, tentando adequá-los a realidade informal do sistema político nacional e também ao próprio pensamento arredio da sociedade frente a sua instituição.

Mesmo não previsto expressamente na legislação maior da Carta Constitucional, os limites a aplicação da contribuição de melhoria e a necessidade inequívoca da demonstração da valorização dos imóveis, seguem recepcionadas pela Constituição Federal, como norma infraconstitucional específica acerca de matéria, tratada de forma geral na Carta Magna de 1988.

Desta forma, implementada ao Código Tributário Nacional em seus arts. 81 e 82 e ao Decreto-Lei 195/67 a força legislativa competente para positivar a matéria em comento, resguardando a necessidade da plus valia imobiliária como fato gerador da contribuição de melhoria.

Da mesma maneira que a necessidade de se observar os limites global (custo total) e individual (valorização imobiliária).

Buscou-se no transcorrer do presente artigo estender a compreensão acerca da contribuição de melhoria, sua aplicabilidade observando os princípios básicos do tributo, assim como a necessidade de respeitar-se a capacidade contributiva, dos contribuintes passiveis da cobrança.

Do mesmo modo, a necessidade de observar os preceitos legais, dos requisitos trazidos pelo art. 82 do CTN e pelo art. 5ํㅓ do Decreto-Lei 195/67, com ênfase a discussão que se apresentou relativa a não ser necessária lei específica para cada obra realizada, desde realizada dentro das normas legais dispostas.

Atendo-se a análise superficial da natureza jurídica vinculada da contribuição de melhoria, que assim como a taxa, necessita de atividade estatal para existir.

Em virtude do disposto pode-se ver que a contribuição de melhoria, encontrase como tributo válido e incorporado ao ordenamento tributário nacional, carecendo 
de interesse dos entes públicos em aplicá-la da forma correta, nos preceitos teóricos vigentes.

Visto que a aplicação correta da contribuição de melhoria seria de grande valia, numa realidade de poucos recursos e investimentos em infraestrutura e urbanização de nossas cidades.

Não há, entretanto, uma "fórmula mágica" ou uma teoria absoluta que seja aplicável a todas as ordens tributárias que se utilizam desse tributo, existem mais fatores que dificultam sua aplicabilidade, além da teoria utilizada.

Há fatores sociais e políticos que diferenciam o modelo ao qual determinado sistema tributário deve seguir. É preciso adequar-se dentro dos fundamentos básicos do tributo. Desse modo, há de se adaptar o tributo a cada realidade social, pois as mesmas teorias e formas possuem variações de resultados em sistemas tributários diferentes.

Os limites (valorização individual e custo total), por vezes, dificultam a aplicação do tributo, tornando-o mais complexo, mas não sendo os únicos empecilhos à aplicabilidade do tributo no ordenamento tributário nacional.

No sistema tributário brasileiro, não demonstrou êxito a teoria aplicada, ou seja, mista (limites - valorização individual e custo total), restando, pois, a discussão doutrinária acerca de qual modelo, definitivamente, melhor se enquadraria ao cenário social-político nacional.

Há os que defendam a utilização do modelo alemão, mais simples, sem limite individual (valorização individual), apenas limite global (custo total da obra) e, outrossim, sem a necessidade da demonstração efetiva da valorização imobiliária e, talvez, por isso, mais aplicável à realidade pouco formal brasileira.

Outros defendem a aplicação correta nos moldes enunciados nas legislações acerca da matéria, opinando por uma mudança, não no sistema aplicado, mas na forma como o tributo é visto.

Seria necessária uma mudança política e social na maneira como é aplicada a contribuição de melhoria, instituindo o tributo na forma como prevista em lei, ressalvando-se as garantias aos contribuintes beneficiados e demonstrando transparência e lisura no processo tributário. 


\section{REFERÊNCIAS}

ALEXANDRE, Ricardo. Direito Tributário Esquematizado. 4. ed. São Paulo: Método, 2010.

AMARO, Luciano. Direito Tributário Brasileiro. 18. ed. São Paulo: Saraiva, 2012.

ÁVILA, Alexandre Rossato. Curso de Direito Tributário. 6. ed. Porto Alegre: Verbo Jurídico, 2011.

BALEEIRO, Aliomar. Direito Tributário Brasileiro. 3. ed. Rio de Janeiro: Forense, 1971.

BRASIL. Constituição Federal, Código Tributário, Código Comercial. 9. ed. Porto Alegre: Verbo Jurídico, 2010.

BRASIL. Constituição da República dos Estados Unidos do Brasil (de 16 de Julho de 1934). Disponível em:

< http://www.planalto.gov.br/ccivil_03/Constituicao/Constituicao34.htm >. Acesso em: 20 mai. 2016.

BRASIL. Constituição dos Estados Unidos do Brasil (de 18 de Setembro de 1946). Disponível em:

< http://www.planalto.gov.br/ccivil_03/Constituicao/Constituicao46.htm>. Acesso em: 20 mai. 2016.

BRASIL. Constituição da República Federativa do Brasil de 1967. Disponível em: <http://www.planalto.gov.br/ccivil_03/Constituicao/Constituicao67.htm>. Acesso em: 23 mai. 2016.

BRASIL. Decreto-Lei № 195, De 24 De Fevereiro De 1967. Dispõe sobre a cobrança da Contribuição de Melhoria. Disponível em <http://www.planalto.gov.br/ccivil_03/decreto-lei/del0195.htm>. Acesso em: 26 jun. 2016.

BRASIL. Emenda Constitucional № 1, de 17 de Outubro de 1969. Disponível em: http://www.planalto.gov.br/ccivil_03/Constituicao/Constituicao67EMC69.htm. Acesso em: 13 mai. 2016.

BRASIL. Emenda Constitucional № 18, de 1ํ de Dezembro de 1965. Reforma do Sistema Tributário. Disponível em: <http://www.planalto.gov.br/ccivil_03/Constituicao/Emendas/Emc_anterior1988/emc1 8-65.htm. Acesso em: 06/06/2016.

BRASIL. Lei no 5.172, de 25 de outubro de 1966 . Dispõe sobre o Sistema Tributário Nacional e institui normas gerais de direito tributário aplicáveis à 
União, Estados e Municípios. Disponível em:

$<$ http://www.planalto.gov.br/ccivil_03/leis/L5172Compilado.htm>. Acesso em: 05 jun. 2016.

BRASIL. Supremo Tribunal Federal - Al: $\mathbf{7 4 1 6 9 4}$ RS, Relator: CÁRMEN LÚCIA, Data de Julgamento: 03/03/2009, Data de Publicação: DJe-062 DIVULG 31/03/2009 PUBLIC 01/04/2009. http://stf.jusbrasil.com.br/jurisprudencia/3609164/agravo-de-instrumento-ai-741694. Acesso em: 12 de mai. de 2016.

BRASIL. Supremo Tribunal Federal - Al: 694836 SP, Relator: Min. ELLEN GRACIE, Data de Julgamento: 24/11/2009, Segunda Turma, Data de Publicação: DJe-237 DIVULG 17-12-2009 PUBLIC 18-12-2009: Disponível em: http://stf.jusbrasil.com.br/jurisprudencia/6187521/agregno-agravo-de-instrumento-ai694836-sp. Acesso em: 30 de mai. De 2016

BRASIL. Supremo Tribunal Federal - RE: 704954 SP, Relator: Min. DIAS TOFFOLI, Data de Julgamento: 17/12/2012, Data de Publicação: DJe-023 DIVULG 01/02/2013 PUBLIC $04 / 02 / 2013$. http://stf.jusbrasil.com.br/jurisprudencia/23041140/recurso-extraordinario-re-704954sp-stf. Acesso em: 25 de mai. De 2016.

BRASIL. Superior Tribunal de Justiça - AgRg no AREsp: 406324 PR 2013/03321938, Relator: Ministro BENEDITO GONÇALVES, Data de Julgamento: 27/03/2014, T1 - PRIMEIRA TURMA, Data de Publicação: DJe 09/04/2014. Disponível em: <http://stj.jusbrasil.com.br/jurisprudencia/152376871/agravo-regimental-no-recursoespecial-agrg-no-resp-1303516-rs-2011-0156519-8>. Acesso em: 25 de mai. De 2016.

BRASIL. Superior Tribunal de Justiça - REsp: 147094 PR 1997/0062530-3, Relator: Ministro BENEDITO GONÇALVES, Data de Julgamento: 15/02/2011, T1 PRIMEIRA TURMA, Data de Publicação: DJe 21/03/2011. Disponível em: http://stj.jusbrasil.com.br/jurisprudencia/18674105/recurso-especial-resp-147094-pr1997-0062530-3. Acesso em: 12 de mai. De 2016.

BRASIL. Superior Tribunal de Justiça - REsp: 927846 RS 2007/0038580-3, Relator: Ministro LUIZ FUX, Data de Julgamento: 03/08/2010, T1 - PRIMEIRA TURMA, Data de Publicação: DJe 20/08/2010. Disponível em: http://stj.jusbrasil.com.br/jurisprudencia/15955623/recurso-especial-resp-927846-rs2007-0038580-3. Acesso em: 15 de jun. de 2016.

BRASIL. Tribunal de Justiça/SP - APL: 03896021720098260000 SP $0389602-$ 17.2009.8.26.0000, Relator: Geraldo Xavier, Data de Julgamento: 11/04/2013, 14 Câmara de Direito Público, Data de Publicação: 30/04/2013. Disponível em: http://tjsp.jusbrasil.com.br/jurisprudencia/205099540/apelacao-apl-187381720098260068sp-0018738-1720098260068/inteiro-teor-205099553. Acesso em: 30 de mai. De 2016. 
BRASIL. Tribunal de Justiça/RS. Apelação Cível № 70056159213, Segunda Câmara Cível, Tribunal de Justiça do RS, Relator: Almir Porto da Rocha Filho, Julgado em 09/10/2013, Data da publicação: 15/10/2013. Disponível em: http://tjrs.jusbrasil.com.br/jurisprudencia/113486165/apelacao-civel-ac-70056159213-rs. Acesso em: 05 de jun. de 2016.

BRASIL. Tribunal de Justiça/RS. Apelação Cível № 70053333704, Primeira Câmara Cível, Tribunal de Justiça do RS, Relator: Luiz Felipe Silveira Difini, Julgado em 24/04/2013, Data da publicação: 06/05/2013. Disponível em: http://tjrs.jusbrasil.com.br/jurisprudencia/112852104/apelacao-civel-ac-70053333704-rs.

Acesso em: 01 de jun. de 2016

CARVALHO, Rubens Miranda de. Contribuição de Melhoria e Taxas no Direito Brasileiro. São Paulo: Juarez de Oliveira, 1999.

COELHO, Sacha Calmon Navarro. Curso de direito tributário brasileiro. 7. ed. Rio de Janeiro: Forense, 2004.

FABRETTI, Láudio Camargo. Código Tributário Nacional Comentado. 8. ed. São Paulo: Atlas, 2008.

MACHADO, Hugo de Brito. Curso de Direito Tributário. 32. ed. São Paulo, Malheiros: 2011.

MACHADO SEGUNDO, Hugo de Brito. Código Tributário Nacional, Anotações à Constituição, ao Código Tributário Nacional e às Leis complementares 87/1996 e 116/2003, 2. ed. São Paulo: Editora Atlas, 2009.

NOGUEIRA, José Geraldo Ataliba. Natureza Jurídica da Contribuição de Melhoria. São Paulo: Revista dos Tribunais, 1964.

PINTO, Bilac. Contribuição de Melhoria. Rio de Janeiro: Forense, 1939.

SABBAG, Eduardo. Manual de Direito Tributário. 3. ed. São Paulo: Saraiva, 2011.

SILVA, Edgar Neves da, Contribuição de Melhoria. In: MARTINS, Ives Gandra da Silva (Coord.). Curso de Direito Tributário. 13. ed. São Paulo: Saraiva, 2011.

VALLE, Maurício Dalri Timm do; CUNHA, Carlos Renato. In: GRILLO, Fábio Artigas; SILVA, Roque Sérgio D’Andrea Ribeiro da (Coord). Código Tributário Nacional, anotado. Escola Superior da Advocacia. Seccional OAB/PR: 2014.P. 227 